\title{
REKONSTRUKSI PEMIDANAAN DALAM HUKUM PIDANA ISLAM (PERSPEKTIF FILSAFAT HUKUM)
}

\author{
AHMAD SYAFIQ \\ Hakim Pengadilan Negeri KUDUS \\ a.syafiq00@yahoo.com
}

\begin{abstract}
Islamic Criminal Law is a living law in Indonesia, and that the Islamic Criminal Law be enacted or coloring in the criminal law in Indonesia, hence the need for a reconstruction against Islamic Criminal Law, especially in theories of punishment. Reconstruction of punishment in the Islamic Criminal Law in the perspective of legal philosophy can be done by doing the desecration (reinterpretation of the textual sources of law) Islamic Criminal Law and bring it in line with the flow of human history itself, rather than release it from the dimensions of space and time history of human civilization, to realize the goals of Islamic law is philosophically contained in maqasid al shariah ie benefit or blessing for the universe (rahmatan lil 'alamin).
\end{abstract}

Keywords: reconstruction, theories of punishment, maqasid al shariah;

\begin{abstract}
Abstrak
Hukum Pidana Islam adalah merupakan hukum yang hidup dalam masyarakat Indonesia, dan agar Hukum Pidana Islam dapat berlaku atau mewarnai dalam kancah hukum pidana di Indonesia, maka perlu adanya suatu rekonstruksi terhadap Hukum Pidana Islam khususnya dalam hal pemidanaannya. Rekonstruksi pemidanaan dalam Hukum Pidana Islam dalam perspektif filsafat hukum dapat dilakukan dengan jalan melakukan desakralisasi (melakukan tafsir ulang terhadap sumber hukum tekstual) Hukum Pidana Islam dan membawanya sesuai dengan alur sejarah manusia itu sendiri, bukan malah melepaskannya dari dimensi ruang dan waktu sejarah peradaban umat manusia, untuk mewujudkan cita Hukum Islam yang secara filsafati terkandung dalam maqasid al syariah yakni kemaslahatan atau rahmat bagi alam semesta (rahmatan lil 'alamin).
\end{abstract}

Kata Kunci : Rekonstruksi, Teori Pemidanaan, Maqasid Al Syariah;

\section{A. PENDAHULUAN}

Indonesia merupakan negara yang mayoritas penduduknya beragama Islam. Dan bagi pemeluk Agama Islam tentunya memiliki keinginan agar dapat melaksanakan Hukum Islam dalam setiap segi kehidupannya, baik dalam hukum perdata, pidana, maupun hukum tata usaha negara.

Namun demikian, Indonesia bukanlah negara Islam, melainkan negara hukum yang berdasarkan Pancasila. Dalam lapangan hukum perdata, Hukum Islam sudah terakomodir dalam Kompilasi Hukum Islam yang menjadi hukum materiil di Pengadilan Agama. Sedangkan dalam lapangan hukum pidana, Hukum Islam masih belum terakomodir.

Hukum Pidana Islam terkesan sangat kejam, karena adanya hukuman potong tangan untuk pencuri, rajam untuk pidana perzinahan, sehingga Hukum Pidana Islam cenderung ditinggalkan. Hal inilah yang menjadi bahan pemikiran penulis, bahwa sesungguhnya Hukum Pidana Islam adalah merupakan hukum yang hidup (living law) dalam masyarakat Indonesia. Dan agar Hukum Pidana Islam dapat berlaku atau mewarnai dalam kancah hukum pidana di Indonesia, maka perlu adanya suatu rekonstruksi terhadap Hukum Pidana Islam khususnya dalam hal pemidanaannya.

Makna rekonstruksi dapat dipahami dengan pembaharuan atau reaktualisasi. Dan ini memiliki tiga kandungan makna, yaitu:

(1) Merekonstruksi atau memperbaharui dengan hal yang sudah pernah ada sebelumnya (menghidupkan kembali); 
(2) Merekonstruksi atau memperbaharui sesuatu yang sudah kadaluarsa (tambal sulam);

(3) Merekonstruksi atau memperbaharui dengan bentuk yang baru sama sekali/

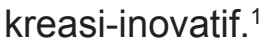

Persoalan rekonstruksi Hukum Islam dipengaruhi oleh dua hal, yaitu :

(1) Stimulasi dari perkembangan modern dunia Barat yang demikian maju dalam segala hal, sehingga memicu dan memaksa dunia Islam untuk menyesuaikan sedemikian rupa dengan perkembangan tersebut. Teori ini seringkali dipakai oleh kelompok sekuler;

(2) Adanya fleksibilitas dari ajaran Islam itu sendiri secara substantif. Artinya, untuk tetap eksis maka ajaran Islam harus mampu bergerak secara dinamis sehingga tidak ketinggalan zaman. Teori kedua ini merupakan jargon utama dari kelompok modernis. ${ }^{2}$

Kedua teori ini saling mendukung, dan sesuai dengan kaidah Ushul fiqh :

$$
\begin{gathered}
\text { تغير ألأحكام بتغير ألأمكان والأزمان } \\
\text { "perubahan hukum sesuai dengan } \\
\text { perubahan ruang dan waktu" }
\end{gathered}
$$

Hal ini sudah diwujudkan oleh Imam Syafi'i yang terkenal dengan adanya qaul qadim (pendapat terdahulu/lama) dan qaul jadid (pendapat baru). Karena kedua pendapat Imam Syafi'i tersebut dikeluarkan pada tempat dan waktu serta keadaan sosial masyarakat yang berbeda. Sehingga dapat dipahami bahwa rekonstruksi atau pembaharuan dalam Hukum Islam telah ada sejak lama.

Islam adalah way of life (jalan kehidupan) atau problem solving (jalan keluar) bagi kehidupan manusia. Dan untuk mewujudkannya dalam pelaksanaan Hukum Pidana Islam, maka diperlukan pemahaman yang komprehensif, holistik

1 Abu Husain Ahmad bin Faris bin Zakaria, Mu'jam Maqayis al-Lughah, 1979, Beirut: Dar al-Fikr li alThaba'ah wa al-Nasyr, Vol. 1., hlm. 306

2 Rifyal Ka'bah dan Bustami Said, 1987, Reaktualisasi Ajaran Islam: Pembaharuan Agama Visi Modernis dan Pembaharuan Agama Visi Salaf, Jakarta: Minaret, hlm. 50 dan proporsional tentang filosofi pemidanaan dalam Hukum Pidana Islam. Sehingga nantinya Hukum Pidana Islam dapat diterima dan tidak dipinggirkan karena dianggap kuno, kejam, sadis, dan tidak humanis.

Dari permasalahan diatas, maka dapat ditarik suatu permasalahan untuk dikaji adalah : apakah pemidanaan dalam Hukum Pidana Islam dapat direkonstruksi apabila dikaji dari perspektif filsafat hukum ?

\section{B. PEMBAHASAN}

\section{a. Teori Pemidanaan dalam Hukum Pidana Islam}

Pemidanaan dalam istilah Bahasa Arab sering disebut 'uqubah, yaitu bentuk balasan bagi seseorang atas perbuatannya yang melanggar ketentuan syara' yang ditetapkan oleh Allah dan RasulNya untuk kemaslahatan manusia. ${ }^{3}$

Tujuan dari adanya pemidanaan dalam syari'at Islam merupakan realisasi dari tujuan Hukum Islam itu sendiri, yakni sebagai pembalasan atas perbuatan jahat, pencegahan secara umum dan pencegahan secara khusus serta perlindungan terhadap hak-hak si korban. Definisi lain menyebutkan bahwa pemidanaan adalah suatu penderitaan yang dibebankan kepada seseorang akibat perbuatannya melanggar aturan. ${ }^{4}$ Pemidanaan dengan hukuman tertentu dimaksudkan untuk mendatangkan kemaslahatan umat dan mencegah kedzaliman atau kemadlaratan. ${ }^{5}$

Ketika tujuan pemidanaan adalah untuk memperbaiki individu, menjaga masyarakat, dan memelihara kehidupan mereka, pemidanaan wajib berdiri diatas suatu nilai dasar yang dapat mewujudkan tujuan-tujuan tersebut supaya pemidanaan dapat memenuhi tugas yang seharusnya. Nilai-nilai dasar

3 A. Rahman Ritonga, dkk.,1997, Ensiklopedi Hukum Islam, Jakarta: Ichtiar Baru Van Hoeve,1997, hlm. 1871

4 Abd. Al-Qadir Awdah, aal-Tasyri' al-Jina'l al-Islami, Bairut: Daral-Fikr, t.t. hlm. 214

5 M. Hasbi Ash-Shiddiqie, 1975, Filsafat Hukum Islam, Jakarta: Bulan Bintang, hlm. 177 
yang mewujudkan tujuan pemidanaan adalah sebagai berikut :

- Pemidanaan yang dijatuhkan dapat mencegah semua orang untuk melakukan tindak pidana, sebelum tindak pidana itu terjadi. Apabila tindak pidana itu telah terjadi, pemidanaan itu untuk mendidik pelaku tindak pidana dan mencegah orang lain untuk meniru atau mengikuti perbuatan pelaku tindak pidana. Atas dasar ini, sebagian fuqaha (ahli Hukum Islam) mengartikan pemidanaan sebagai suatu pencegah sebelum terjadinya tindak pidana dan pencegahan bagi anggota masyarakat yang lain setelah dijatuhkannya pemidanaan, juga dengan adanya pengetahuan atas diundangkannya peraturan hukum yang mengandung sanksi pemidanaan tersebut, akan mencegah pengulangan tindak pidana oleh pelaku. ${ }^{6}$

- Batasan pemidanaan adalah untuk kebutuhan dan kemaslahatan masyarakat. Apabila kemaslahatan masyarakat menuntut pemidanaan diperberat, maka pemidanaan diperberat. Demikian pula, sebaliknya apabila kemaslahatan masyarakat menuntut pemidanaan diperingan, maka pemidanaan diperingan. Hal ini menunjukkan bahwa pemidanaan tidak diperbolehkan melebihi atau kurang dari kemaslahatan masyarakat umum. ${ }^{7}$

- Apabila untuk memelihara masyarakat dari kejahatan tindak pidana, si pelaku dituntut untuk dibunuh atau kejahatannya dicegah dari masyarakat, pemidanaan yang harus dijatuhkan adalah hukuman mati, atau memenjarakannya sampai si pelaku tindak pidana mati, selama ia belum bertaubat dan keadaannya belum menjadi baik. ${ }^{8}$

6 Ibnu Hammam, Syarah Fath al Qadir, Jilid IV, tt. hlm. 112

7 Al Mawardi, al Ahkam al Sultaniyyah, Penerbit : al Sa'adah dan al Wathan, cet. I, tt. hlm. 206

8 Syaraf al Din Musa al Hajjawiy, al lqna', Penerbit : al Misriyyah, cet. I, jilid IV, tt. hIm. 271-272
- Semua pemidanaan yang menghasilkan kemaslahatan individu dan memelihara kemaslahatan masyarakat adalah pemidanaan yang harus disyariatkan. Karena itu tidak boleh membatasi dengan hanya menerapkan pemidanaan tertentu tanpa pemidanaan yang lainnya.

- Mendidik si pelaku tindak pidana bukan berarti bentuk balas dendam atas dirinya, melainkan sebagai perbaikan dirinya. Semua pemidanaan dengan berbagai bentuknya, adalah pendidikan, perbaikan, dan pencegahan yang saling berbeda sesuai dengan perbedaan tindak pidana. Pemidanaan disyariatkan sebagai kasih sayang (rahmat) dan kebaikan dari Allah terhadap hambaNya. ${ }^{9}$

Sehingga prinsip dasar untuk mencapai tujuan dari adanya pemidanaan tersebut diatas, dapat dibuat menjadi beberapa kriteria sebagai berikut:

1. Hukuman itu bersifat universal, yaitu dapat menghentikan orang dari melakukan suatu tindak kejahatan, bisa menyadarkan dan mendidik bagi pelakunya.

2. Penerapan materi hukumannya sejalan dengan kebutuhan dan kemaslahatan masyarakat.

3. Seluruh bentuk hukuman harus dapat menjamin dan mencapai kemaslahatan pribadi dan masyarakat.

4. Hukuman tersebut bertujuan untuk melakukan perbaikan terhadap pelaku tindak pidana. ${ }^{10}$

Dalam masalah tindak pidana (criminal act), terdapat dua hal yang tidak dapat dipisahkan dan merupakan satu mata rantai yang tidak akan pernah terputus, yaitu tindak pidana dan pemidanaan. Suatu bentuk perintah dan larangan saja tidaklah cukup untuk mendorong seseorang meninggalkan suatu perbuatan

9 Ibnu Taimiyah, al Ikhtibarat al Ilmiyah, Penerbit Kurdistan, tt. hlm. 171

10 A. Rahman Ritonga, Op. Cit., hlm. 1872 
atau melaksanakannya, untuk itulah diperlukan sanksi berupa pemidanaan bagi siapa saja yang melanggarnya. ${ }^{11}$

Pemidanaan dalam kajian Hukum Pidana Islam (fiqh jinayah) dikelompokkan dalam beberapa jenis, yaitu:

1. Pemidanaan dilihat dari keterkaitan antara satu pemidanaan dengan pemidanaan yang lainnya. Dalam hal ini ada empat macam:

a. Pidana pokok, yaitu pemidanaan yang diterapkan secara definitif, artinya hakim hanya menerapkan sesuai apa yang telah ditentukan oleh nash. Dalam figh jinayah pemidanaan ini disebut sebagai jarimah hudud.

b. Pidana pengganti, pemidanaan yang diterapkan sebagai pengganti karena pidana pokok tidak dapat diterapkan dengan alasan yang sah/benar. Misalnya qishash diganti dengan diyat, dan diyat diganti dengan dimaafkan.

c. Pidana tambahan, yaitu pemidanaan yang menyertai pidana pokok tanpa adanya keputusan hakim tersendiri. Misalnya bagi pelaku qazaf (menuduh berzina) diberlakukan pemidanaan berupa hilangnya hak persaksian dirinya, dan hilangnya hak pewarisan bagi pelaku pembunuhan.

d. Pidana pelengkap, yaitu tambahan pidana pokok dengan melalui keputusan hakim secara tersendiri. Pidana pelengkap sejalan dengan pidana tambahan karena keduanya merupakan konsekuensi/akibat dari pidana pokok. Perbedaan antara pidana tambahan dengan pidana pelengkap adalah pidana tambahan tidak memerlukan adanya putusan hakim tersendiri, sedangkan pidana pelengkap

11 Abdul Salam, 1987, Figh Jinayat (Hukum Pidana Islam), Yogyakarta: Ideal, hlm. 52 memerlukan adanya putusan hakim tersendiri.

2. Pemidanaan dilihat dari kewenangan hakim dalam memutuskan perkara.

Dalam hal ini ada dua macam :

a. Pemidanaan yang bersifat terbatas, yakni ketentuan pidana yang ditetapkan secara pasti oleh nash, atau dengan kata lain, tidak ada batas tertinggi dan terendah. Misalnya hukuman dera 100 kali bagi pelaku zina dan hukuman dera 80 kali bagi pelaku penuduh zina.

b. Pemidanaan yang memiliki alternatif untuk dipilih.

3. Pemidanaan dilihat dari obyeknya. Dalam hal ini ada tiga macam:

a. Pemidanaan fisik, seperti potong tangan, rajam dan lainnya.

b. Pemidanaan yang berkenaan dengan psikologis, ancaman dan teguran.

c. Pemidanaan benda, ganti rugi, diyat dan penyitaan harta. ${ }^{12}$

Dari uraian di atas, maka sangat wajar jika dalam semua tradisi hukum pidana, perhatian yang paling utama adalah pada "bentuk pemidanaan" yang akan dibebankan kepada setiap pelaku tindak pidana. Dengan demikian, pembahasan tentang rekonstruksi pemidanaan sesungguhnya merupakan langkah yang sangat strategis untuk memahami suatu sistem hukum pidana tertentu termasuk Hukum Pidana Islam. Pada kenyatannya aplikasi suatu sistem pidana apapun tidak akan mungkin dapat dijustifikasi tanpa suatu kejelasan bahwa teori yang dibangun di dalamnya dapat memenuhi tujuan dari sistem pidana itu sendiri.

Sebagai langkah awal untuk memahami bangunan filosofis sistem

12 Marsum, 1988, Hukum Pidana Islam, Yogyakarta: Fakultas Hukum UII, hlm. 126. Lihat juga dalam Makhrus Munajat, 2008 Hukum Pidana Islam di Indonesia, Yogyakarta: Bidang Akademik UIN Sunan Kalijaga, hlm. 116-117. Dan lihat juga dalam Jazuli,1997, Fiqh Jinayat: Upaya Menanggulangi Kejahatan dalam Islam, Jakarta: Rajawali Press, hlm. 24 
Hukum Pidana Islam, maka terlebih dahulu akan dijelaskan tentang teori pemidanaan yang dibangun di dalam Hukum Pidana Islam, di samping sekedar membandingkannya dengan sistem hukum pidana Barat sebagai alat untuk mempertajam analisa.

Berbeda dengan sistem hukum pidana Baratyang mendasarkan dan menjustifikasi teori pemidanaannya pada pandangan tentang utilitas sosial (social utility), maka teori pemidanaan dalam sistem hukum pidana Islam lebih didasarkan pada sumber teks wahyu Tuhan yang dituliskan di dalam Al-Qur'an dan Sunnah Rasul Muhammad. Permasalahannya adalah bahwa pada tataran praktisnya baik Al-Qur'an maupun Sunnah Nabi sesungguhnya hanya mengandung sebagian kecil teori mengenai hal ini. Aturan-aturan yang diberikan oleh kedua sumber tersebut lebih bersifat umum dan sangat mungkin untuk diinterpretasikan secara variatif. Walaupun tidak diingkari adanya kenyataan bahwa kedua sumber hukum Islam itu mengatur secara spesifik beberapa aturan mengenai pemidanaan terhadap suatu tindak pidana tertentu, namun aturan-aturan tersebut tidaklah banyak dan umumnya berhubungan dengan berbagai macam topik.

\section{b. Filosofi Pemidanaan dalam Hukum Pidana Islam}

Agama Islam adalah cara hidup yang paling sempurna yang membawa rahmatan lil 'alamin (kasih sayang bagi seluruh alam semesta). Islam terus hidup dan senantiasa sesuai dengan perkembangan zaman dan segala keadaan yang dihadapi oleh umatnya, elastik dan tidak stagnan. Allah Maha Bijaksana (Al-Hakim), di mana Dia tidak menciptakan sesuai dengan main-main atau penuh dengan kebathilan. Dia tidak akan membuat sesuatu hukum untuk siasia, karena Allah SWT, sama sekali tidak memerlukan kepada hamba-hambaNya. Segala perintah, larangan penghalalan, pengharaman, atau diperbolehkan semata-mata hanya untuk kemaslahatan manusia agar mereka jauh dari kesesatan dan kerusakan.

Ibnu Qayyim menjelaskan bahwa dasar dan asas syari'at adalah untuk mewujudkan kemaslahatan manusia di dunia dan akhirat. Menurutnya, seluruh hukum itu mengandung keadilan, rahmat, kemaslahatan dan hikmah, jika keluar dari keempat nilai yang dikandungnya, maka hukum tersebut tidak dapat dinamakan syari'at. ${ }^{13}$

Dan untuk mewujudkan kemaslahatan tersebut, maka secara filsafati tujuan adanya penetapan hukum dalam Hukum Islam terangkum dalam maqasid al syari'ah (yang pengertian secara bahasa adalah tujuan dari kebiasaan atau sunnah). ${ }^{14}$

Ada beberapa pendapat ulama dalam mendefinisikan maqasid al syari'ah, antara lain adalah :

- Abu Zahrah berpendapat bahwa maqasid al syari'ah adalah tujuan puncak yang hendak dicapai yang terdapat dalam setiap Hukum Islam, yaitu kemaslahatan. Dan kemaslahatan ini adalah kemaslahatan yang bersifat hakiki, bukan kemaslahatan yang menuruti keinginan hawa nafsu. ${ }^{15}$

- Abdul Wahab Khallaf berpendapat bahwa maqasid al syariah adalah keinginan pembuat hukum (syari') dalam mensyariatkan hukum adalah demi kemaslahatan (kebaikan) umat manusia. $^{16}$

- Wahbah Al Zuhaili berpendapat bahwa maqasid al syariah adalah nilai-nilai

13 Ibn al Qayyim al Jawziyah, I'lam al-Muwaqi'in Rabb al- 'Alamin, Dar al-Fikr, Beirut, tt. Jilid III hlm.3. Lihat juga dalam Izzuddin Ibn Abd al-salam, Qawaid alAhkam fi Mashalih al-Anam, Dar al-Jail, Beirut, tt., jilid II, hIm. 72. Dan lihat juga dalam Wahbah Zuhaili, 1986, Ushul al-Figh al-Islami, Dar al-Fikr, Beirut, Jilid II, hlm. 1017.

14 Louis Ma'luf, 1986, al Munjid, Dar al Masyriq, Beirut, hIm. 382

15 Muhammad Abu Zahrah, 2008, Ushul Figh, Pustaka Firdaus, Jakarta, hlm. 548

16 Abdul Wahab Khallaf, 1978, Ilmu Ushul al Fiqh, Dar al Qalam, Kuwait, hlm. 197 
dan sasaran syara'yang tersirat dalam segenap atau bagian terbesar dari hukum-hukumnya. Nilai-nilai dan sasaran itu dipandang sebagai tujuan dan rahasia syari'ah, yang ditetapkan oleh al Syari' (Sang Pembuat Hukum) dalam setiap ketentuan hukum. ${ }^{17}$

- Imam Ghazali berpendapat bahwa maqasid al syariah adalah maslahat yang dicapai oleh manusia baik di dunia maupun di akhirat, baik maslahat itu dicapai dengan cara jalbu al manafi' (menarik manfaat) atau dengan cara daf al darar (menolak bahaya/kerusakan). ${ }^{18}$

- Al Syatibi berpendapat bahwa maqasid al syariah adalah maslahah atau kebaikan dan kesejahteraan umat manusia. ${ }^{19}$

Dari beberapa definis diatas, maka dapat penulis simpulkan bahwa tujuan disyariatkannya Hukum Islam adalah demi kebaikan (maslahah) bagi umat manusia. Umat manusia ini diartikan secara umum tidak hanya umat Islam saja, sebagaimana penjelasan dalam al Qur'an :

"Dan tidaklah Kami mengutus kamu, melainkan untuk (menjadi) rahmat bagi semesta alam." (QS. al Anbiya (21):107) ${ }^{20}$

Untuk menuju kepada maqasid al syariah tersebut, Hujjatul Islam Abul Hamid Al-Ghazali telah membuat satu perbahasan khusus yang menjelaskan tentang maslahah sebagai asal yang tidak jelas (ash mauhum) dan membaginya kepada tiga (3) tingkatan yang kemudiannya dirinci oleh Imam Asy-Syathibi, ${ }^{21}$ sebagai berikut :

17 Wahbah al Zuhaili, 1986, Ushul al Fiqh al Islami, Dar al Fikr, Damaskus, hlm.225

18 Al Ghazali, al Mustasyfa, Dal al Fikr, 1997, Beirut, hlm.258

19 Abu Ishaq al Syatibi, 2004, al Muwafaqat fi Ushul al Syariah, Dar al Kutub al IImiah, Beirut, hlm. 219

20 Kementerian Urusan Agama Islam Kerajaan Arab Saudi, 1419 H, Al Qur'an dan Terjemahannya, hlm. 508

21 Al Syatibi, Op. Cit., hlm. 221
1. Daruriyat (primer) artinya harus ada demi kemaslahatan hamba, yang jika tidak ada, akan menimbulkan kerusakan, misalnya rukun Islam. Daruriyat dijelaskan dengan lebih rinci mencakup lima tujuan (alkulliyyat al-khamsah), iaitu :

1.1. menjaga agama ( $h i f d z$ al din);

1.2. menjaga jiwa (hifdz al nafs);

1.3. menjaga akal (hifdz al 'aql);

1.4. menjaga keturunan (hifdz al nasl);

1.5. menjaga harta (hifdz al mal). Sehingga tujuan dari maqasid al syariah akan tercapai jika terpenuhinya penjagaan kelima unsur yang telah disebutkan tadi.

2. Hajiyat (sekunder) maksudnya sesuatu yang diperlukan untuk menghilangkan kesempitan, seperti rukhsah (keringanan) tidak berpuasa bagi orang sakit.

3. Tahsiniyat (suplementer) artinya sesuatu yang diambil untuk kebaikan kehidupan dan menghindarkan keburukan, semisal akhlak yang mulia, menghilangkan najis, dan menutup aurat.

Beberapa ahli kriminologi dan psikologi sosial berpendapat bahwa suatu tindak pidana yang dapat dikenakan pemidanaan adalah suatu perbuatan yang telah diperhitungkan secara rasional. Artinya, perbuatan tersebut telah terpenuhi unsurunsur pidananya sehingga pelakunya dapat dimintai pertanggungjawaban pidana. Jadi, salah satu unsurnya adalah "kesengajaan". Hal ini sejalan dengan hadis Nabi yang mengatakan bahwa suatu perbuatan itu tergantung dari niat yang melandasi perbuatan tersebut.

Dalam Hukum Pidana Islam, pemidanaan terhadap tindak pidana yang masuk dalam kategori hudud adalah minum-minuman keras/memabukkan, mencuri, perampokan, berzina, menuduh orang lain berzina, dan murtad, merupakan bentuk pemidanaan yang secara teoritis 
disebutkan secara eksplisit di dalam AlQur'an dan Sunnah Nabi Muhammad. Selain dari qishas (retaliation), yang merupakan pemidanaan untuk perbuatan pembunuhan atau melukai seseorang, semua tindak pidana yang lainnya masuk dalam kategori ta'zir. Walaupun mayoritas ulama sepakat dengan pembagian seperti ini namun tidak berarti tidak ada ulamaulama minoritas yang berpendapat lain. Perbedaan ini tampaknya terfokus pada jenis perbuatan apa yang masuk dalam kategori hudud, apakah lebih dari enam perbuatan sebagaimana yang disebutkan di atas atau kurang dari enam, sebagai akibat dari pemahaman mereka yang berbeda-beda terhadap sumber tekstual ayat-ayat Al-Qur'an maupun hadis tersebut. ${ }^{22}$

Tidak banyak kajian yang membahas tentang sifat dasar dan tujuan dari aspek-aspek pemidanaan dalam hukum pidana Islam ini. Para ahli Hukum Islam, terutama yang klasik dan menengah, tampaknya tidak begitu tertarik dengan bahasan semacam ini. Terutama dalam hal hukuman hadd, para ulama tampaknya lebih dipengaruhi oleh suatu pemahaman bahwa sumber-sumber tekstual sudah memberikan rumusan yang matang dan jelas tentang bentuk pemidanaan yang harus diberikan sehingga mereka cenderung untuk tidak lagi memikirkan legal reasoning (alasan hukum) yang ada dibalik bentuk-bentuk pemidanaan tersebut.

Namun begitu, di tengah-tengah minimnya produk-produk analisis mengenai teori dasar pemidanaan ini, beberapa ulama sejak periode awal sesungguhnya juga sudah berupaya ke arah pemikiran kritis terhadap lembaga pemidanaan ini. Ibn al-Qayyim, sudah berusaha untuk menganalisis lembaga pemidanaan ini dalam keilmuan Hukum

22 Mohammed S. El Awa, 1982, Punishment in Islamic Law, Indianapolis: American Trust Publications, hlm. 2
Pidana Islam. ${ }^{23}$ Namun sayangnya setelah masa Ibn al-Qayyim, subjek ini kembali banyak dilupakan oleh para Muslim juris. Baru pada periode modern inilah para ahli Hukum Islam kembali membahas dengan detail topik ini dalam karya-karya mereka.

Hukum Islam mendasarkan rumusan pemidanaan dalam pelanggaran pidana pada dua aspek dasar, yaitu: ganti rugi/ balasan (retribution) dan penjeraan (deterrence). ${ }^{24}$ Berikut dapat dijelaskan dua aspek dasar rumusan pemidanaan dalam Hukum Pidana Islam tersebut, yaitu: 1. AspekGantiRugi/Balasan(Retribution).

Fungsi retributif suatu pemidanaan merupakan subjek yang paling banyak diperbincangkan oleh para ahli Hukum Pidana Islam, di samping fungsi penjeraannya. Hal ini tampaknya dipengaruhi oleh keberadaan ayatayat Al-Qur'an itu sendiri yang banyak membahas tentang aspek retribusi ini.

Misalnya, ayat-ayat Al-Qur'an berikut ini :

"Sesungguhnya pembalasan terhadap orang-orang yang memerangi Allah dan rasul-Nya dan membuat kerusakan di muka bumi, hanyalah mereka dibunuh atau disalib, atau dipotong tangan dan kaki mereka dengan bertimbal balik, atau dibuang dari negeri (tempat kediamannya). yang demikian itu (sebagai) suatu penghinaan untuk mereka didunia, dan di akhirat mereka beroleh siksaan yang besar" [Qs. al Maidah (5): 33] ${ }^{25}$ "Laki-laki yang mencuri dan perempuan yang mencuri, potonglah tangan keduanya (sebagai) pembalasan bagi apa yang mereka kerjakan dan sebagai siksaan dari Allah. Dan Allah Maha Perkasa lagi Maha Bijaksana" [Qs. al Maidah (5): 38] ${ }^{26}$

23 Ibn al Qayyim al Jauziyah, Op. Cit., hlm. 93-111

24 Mohammaed S. El Awa, Op. Cit., hlm. 23-35

25 Kementerian Urusan Agama Islam Kerajaan Arab Saudi, Op. Cit., hIm. 164

26 Ibid, hlm. 165 
"Dan orang-orang yang mengerjakan kejahatan (mendapat) balasan yang setimpal dan mereka ditutupi kehinaan. tidak ada bagi mereka seorang pelindungpun dari (azab) Allah, seakan-akan muka mereka ditutupi dengan kepingan-kepingan malam yang gelap gelita. mereka Itulah penghuni neraka; mereka kekal di dalamnya." [Qs. 10: 27] ${ }^{27}$

Ayat-ayat Al-Qur'an di atas banyak menyebut tentang tujuan suatu pemidanaan sebagai balasan/ ganti rugi atas perbuatan yang melanggar hukum tertentu. Menarik untuk diperhatikan di sini bahwa bahasa Arab untuk kata "balasan", yaitu jaza', dalam Al-Qur'an digunakan untuk kedua arti; pemidanaan (punishment) dan pahala (reward). Dengan demikian, kedua arti kata ini secara filosofis sama-sama digunakan untuk tujuan yang tidak berbeda, yaitu pemberian balasan atas amal perbuatan yang baik atau ganti rugi atas pelanggaran hukum yang telah dilakukan oleh seseorang.

Dalam hal "retribusi" sebagai alasan hukum (legal reasoning) dibalik pemidanaan, terdapat dua hal yang secara inheren menjadi unsur yang harus ada di dalamnya: (a) kekerasan suatu pemidanaan, dan (b) keharusan pemidanaan itu diberikan kepada pelaku perbuatan kriminal. ${ }^{28}$ Bila dibandingkan dengan bentuk pemidanaan dalam sistem hukum pidana lain, maka bentuk pemidanaan yang dituntunkan dalam Hukum Pidana Islam ini dipandang sebagai suatu bentuk pemidanaan yang paling keras.

Menurut Muhammad Qutb, kerasnya hukuman dalam Pidana Islam ini dikarenakan suatu pertimbangan

$27 \mathrm{Ibid}$

28 Abdullah Ahmed al Nai'im, 1990, Toward in Islamic Reformation, Syracuse, New York, Syracuse University Press, hIm. 112-113 psikologis bahwa dalam rangka memerangi kecenderungan para kriminalis untuk melanggar hukum, maka Islam menuntunkan pemidanaan yang keras sebagai balasan kepada tindakan kriminal yang dilakukan sehingga dengan pemidanaan tersebut orang menjadi jera untuk mengulangi perbuatannya lagi. ${ }^{29}$

Kerasnya pemidanaan dalam Hukum Pidana Islam ini, menurut penulis dikarenakan juga dalam teori hukum pembuktian dalam Hukum Pidana Islam sangatlah ketat. Dalam Hukum Pidana Islam tidak dikenal adanya alat bukti petunjuk atau prasangka. ${ }^{30}$ Karena dalam Islam berprasangka adalah dosa dan dilarang. ${ }^{31}$ Sehingga pembuktiannya tidak dapat didasarkan pada petunjuk (dzan), melainkan haruslah pasti. Disinilah salah satu letak perbedaan dalam Hukum Pidana Islam dengan Hukum Pidana barat.

Dalam era modern sekarang ini, pandangan tentang kekerasan pemidanaan dalam Hukum Pidana Islam ini tampaknya lebih dipengaruhi oleh fenomena dominannya bentuk fisicly punishment (pemidanaan fisik) di dalamnya. Hampir semua bentuk pemidanaan untuk tindak pidana yang disebutkan dalam sumber teks Islam

29 Muhammad Qutb, 1967, Manhaj al-Tarbiyyah alIslamiyyah, Beirut: tp., hlm. 231-234

30 Bandingkan dengan alat bukti yang diatur dalam Pasal 184 KUHAP, alat bukti yang sah adalah (a) keterangan saksi, (b) keterangan ahli, (c) surat, (d) petunjuk, (e) keterangan terdakwa. Dan petunjuk dalam Pasal 188 KUHAP disebutkan bahwa petunjuk adalah perbuatan, kejadian atau keadaan, yang karena persesuaian, baik antara yang satu dengan yang lain, maupun dengan tindak pidana itu sendiri, menandakan bahwa telah terjadi suatu tindak pidana dan siapa pelakuknya, dan petunjuk ini hanya dapat diperoleh dari keterangan saksi, surat dan keterangan terdakwa, serta dinilai oleh Hakim berdasarkan hati nuraninya. Lihat dalam R. Soenarto Soerodibroto, 1991, KUHP dan KUHAP, PT. Raja Grafindo Persada, Edisi kelima, Jakarta, hlm. 436-438.

31 Pelarangan ini dimuat dalam al Qur'an surat al Hujurat ayat 12. 
memang berkisar pada pemidanaan yang bersifat fisik, seperti dipotong tangannya, dicambuk, dilempar dengan batu (dirajam) dan lainlainnya. Hal inilah sesungguhnya yang tampaknya menjadi cap kekejaman terhadap bentuk-bentuk hukuman dalam Islam. Persoalannya sekarang adalah apakah cara-cara hukuman semacam ini bersifat tauqifi yang harus dilakukan persis sama sebagaimana ayat Al-Qur'an atau hadis Nabi menuntunkannya, atau sesungguhnya dimungkinkan adanya perubahan bentuk hukuman yang semula hanya terfokus pada siksaan fisik kepada bentuk siksaan baru yang lebih bersifat non-fisik. Kontroversi dan perdebatan tentang teori kekerasan pemidanaan ini tidak hanya terjadi di kalangan umat Islam saja, para ahli filsafat hukum Barat juga memperdebatkan hal yang sama. ${ }^{32}$

Menanggapi persoalan di atas, beberapa ahli berpendapat bahwa apa yang sesungguhnya dibutuhkan bagi pelaku tindak pidana adalah "pengobatan" (treatment) ketimbang pemidanaan yang berat. Artinya, pemidanaan yang diberikan kepada pelaku tindak pidana seharusnya tidak bersifat penyiksaan akan tetapi sekedar mengobati "sakit" yang ia derita. Di sisi lain, para ahli dengan pandangan yang berbeda memandang bahwa pemidanaan yang berat itu diperlukan untuk mencegah meningkatnya angka kriminalitas yang cenderung tinggi. Jadi, lebih merupakan tujuan fungsional menurut kelompok kedua ini.

Sebagaimana yang terlihat dalam analisis Qutb di atas, tampak bahwa para ahli Hukum Pidana Islam masuk dalam kelompok kedua ini. Menurut

32 Virginia Mackey, 1983, Punishment in the Scripture and Tradition of Judaism, Christianity and Islam, New York: National Interreligious Task Force on Criminal Justice, hlm. 151 mereka, pemidanaan yang berat itu harus diberikan sebagai ganti rugi terhadap perbuatan kriminal yang telah dilakukan. Lebih dari itu, khususnya dalam hal pemidanaan hadd, argumen yang lebih khusus lagi dari para ahli Hukum Pidana Islam adalah bahwa pemidanaan yang berat itu memang harus dilakukan karena sesuai dengan perintah Allah Swt. Karenanya, menurut mereka, apapun bentuk pemidanaan itu tetaplah harus dijalankan apa adanya.

Aspek kedua yang inheren dalam pemidanaan yang retributif adalah "keharusan pemidanaan itu diberikan kepada orang yang melakukan tindak pidana". Hal ini dapat dimengerti karena suatu pemidanaan tentunya akan kehilangan sifat retributifnya jika tidak ditimpakan kepada setiap orang yang melakukan tindak pidana.

Kepercayaan terhadap sifat retribusi dalam penjatuhan pidana ini sesungguhnya merupakan suatu hal yang universal sifatnya. Sistem hukum pidana Barat juga mengenal rumusan retribusi ini. Di Inggris, misalnya, tidak hanya publik yang menghendaki pemidanaan yang retributif sifatnya akan tetapi doktrin ini sendiri mempunyai akar yang cukup kuat dalam jurisprudensi dan filsafat hukum Inggris. Hal ini sebagaimana dikatakan oleh Goodhart bahwa "retribusi dalam suatu pemidanaan pada dasarnya merupakan ekspresi dari ketidaksetujuan masyarakat terhadap tindak pidana, dan jika retribusi ini tidak dipertimbangkan, maka berarti ketidaksetujuan masyarakat tersebut menjadi hilang". ${ }^{33}$

2. Aspek Penjeraan (Deterrence) Pemidanaan

Penjeraan menjadi alasan hukum (legal reasoning) dijatuhkannya suatu pemidanaan. Tujuannya yang

33 Arthur Lehman Goodhart, 1953, English Law and the Moral Law, London: Stevens, hlm. 93 
pokok adalah mencegah terulangnya tindak pidana tersebut di kemudian hari. Berbeda dengan retribusi yang lebih cenderung melihat ke belakang dari titik waktu tindak pidana tersebut, maka penjeraan ini proyeksinya adalah ke depan, yaitu kepentingan adanya suatu tindakan pencegahan agar pelanggaran itu tidak terjadi lagi.

Efek dari penjeraan ini mempunyai dua tujuan, yaitu tujuan internal dan general. Pada aspek internal, penjeraan itu ditujukan kepada si pelaku kejahatan tersebut agar jera untuk mengulangi tindakan jahatnya, sedangkan secara umum penjeraan itu diproyeksikan kepada masyarakat secara umum agar takut untuk melakukan tindakan kriminal. Dengan demikian, sifat pokok dari penjeraan ini adalah menumbuhkan rasa takut terhadap pemidanaan. Secara umum, sifat penjeraan pemidanaan ini sampai sekarang masih diterima sebagai salah satu bentuk justifikasi yang efektif dalam proses penjatuhan pidana.

Hukum Pidana Islam adalah sistem hukum yang paling kuat pengadopsiannya terhadap aspek penjeraan ini bila dibandingkan dengan sistem pidana yang lain. Islam memandang sifat penjeraan merupakan hal yang paling utama dalam pemberian pidana. Pandangan seperti ini dapat dilihat dari pendapat-pendapat ulama Islam berkenaan dengan tujuan dijatuhkannya suatu pemidanaan. Karena pandangan seperti inilah maka al-Mawardi mendefinisikan hudud sebagai "pemidanaan penjeraan yang diciptakan oleh Tuhan untuk mencegah manusia melakukan pelanggaran terhadap apa yang dilarangNya dan mengesampingkan apa yang diperintahkanNya" ${ }^{34}$

34 Al Mawardi, Op. Cit, hlm. 221
Kekentalan sifat penjeraan dalam teori pemidanaan dalam Hukum Pidana Islam, baik penjeraan terhadap pelaku tindak pidana maupun masyarakat, merupakan hal yang muncul dalam argumenargumen para ahli Hukum Islam yang umumnya mendukung pandangan teori penjeraan ini sebagai motivasi di balik ketetapan Tuhan tentang pemidanaan hadd.

Terhadap teori penjeraan ini kita pun dapat memahami mengapa beberapa pemidanaan yang dituntunkan dalam Hukum Pidana Islam, seperti pemidanaan untuk perzinahan, misalnya, harus dilakukan di depan orang banyak. Tujuan penjeraan yang umum kepada publik, yaitu agar takut berbuat hal yang serupa, tentunya menjadi alasan rasional dibalik ketetapan ini.

\section{c. Rekonstruksi Teori Pemidanaan dalam Hukum Pidana Islam}

Adanya berbagai kajian terhadap fenomena kriminal dan hukum pidana pada beberapa dekade akhir ini telah membuahkan pemikiran akan pentingnya sifat rasional dalam pemidanaan yang lain selain dua aspek retribusi dan penjeraan sebagaimana disebutkan di atas. Perhatian para ahli phenology modern sekarang ini juga tampak lebih tertuju kepada sifat reformasi (reformation) dari suatu pemidanaan. Bagi para kriminolog, reformasi itu sendiri lebih sinonim dengan arti "pengobatan" (cure).

Kecenderungan ini lebih didasari oleh suatu pemikiran bahwa orang yang melakukan tindak kriminal itu tidak lagi tepat dipandang sebagai "orang yang jelek" akan tetapi "orang yang sakit". Ibarat orang yang sakit, orang yang melakukan tindakan pidana itu sangat membutuhkan pertolongan.

Kerangka epistemologi ini berimbas kepada bentuk-bentuk pemidanaan yang tidak berupa siksaan fisik 
(fisicly punishment) dan pelaksanaan pemidanaannya pun lebih terfokus kepada diri pelaku tindak pidana ansich, tanpa melibatkan orang lain yang tidak tersangkut tindakan kriminal tersebut.

Karenanya bentuk pemidanaan yang paling sering dijatuhkan adalah pemidanaan kurungan/penjara. Pemidanaan fisik (fisicly punishment) seperti cambukan atau siksaan badan lainnya sudah tidak dipraktekkan lagi, dan pemidanaan tersebut tidak perlu lagi dilaksanakan di hadapan umum.

Kemudian muncul suatu persoalan apa sikap para ahli Hukum Pidana Islam menanggapi fenomena semacam ini, dan pastinya tidak mudah menjawabnya. Pro dan kontra pun kemudian muncul di kalangan mereka, namun sampai sekarang mayoritas para ahli Hukum Pidana Islam tampaknya masih cenderung kepada pandangan bahwa dalam bentukbentuk pemidanaan yang sudah diatur secara eksplisit dalam Al-Qur'an dan hadis Nabi maka tidak mungkin dicarikan justifikasi untuk merubahnya. Artinya, dalam hal hukuman hudud dan jinayat, filsafat reformasi hukuman tidak bisa dijadikan sebagai alasan pembenar untuk merubah bentuknya. Potong tangan tetap harus diberlakukan kepada orang yang mencuri, cambukan atau rajam untuk orang yang berzina, qisas untuk tindakan pembunuhan dan sebagainya.

Sikap semacam itu tentunya berasal dari pandangan sebagian besar kalangan ahli Hukum Pidana Islam yang masih cenderung untuk memahami sumbersumber teks agama secara tekstual. Dalam hal-hal yang sudah diatur secara transparan oleh Al-Qur'an dan hadis Nabi, mereka masih belum berani mempertanyakan kemungkinan untuk menyelisihi aturan tersebut dengan alasan lebih memegangi aspek tekstualnya. Oleh karena itu, walaupun mereka percaya pada kaidah: alhukmu yadurru ma'a 'illatihi wujudan wa 'adaman (hukum berdasarkan alasan hukumnya (legal reasoning) yang tampak atau tidak), dan taghayyiril ahkam bi tagayyiril amkan wal azman (perubahan hukum dipengaruhi ruang dan waktu) tetapi pada tataran praktisnya kaidah ini hanya berjalan pada hal-hal yang non-eksplisit dalam kedua sumber teks tersebut.

Dalam hal hukum pidana, kenyataan epistemologis ini tampak kentara sekali di mana para ulama senantiasa mengemukakan argumen religious idealism (bahwa semua bentuk pemidanaan yang dikemukakan Al-Qur'an dan hadis Nabi tidak dapat dirubah karena semata-mata aturan dari Tuhan) di setiap ada usaha-usaha untuk mereinterpretasi bangunan sistem Hukum Pidana Islam tersebut.

Namun begitu, kecenderungan ke arah rekonstruksi Hukum Pidana Islam senantiasa muncul. Kecenderungan semacam ini dirasakan sangat relevan terutama dalam rangka penghadapan antara Islam dan tatanan dunia baru sekarang ini. Untuk itulah gagasan para pemikir Islam modern semacam Abdullahi Ahmed an-Na'im sangat perlu untuk mendapat respon intelektual yang positif. Apa yang diinginkan oleh anNa'im, misalnya, sebenarnya adalah memformat ulang bangunan Hukum Islam disesuaikan dengan lingkungan masyarakat modern yang plural dan terdiri dari berbagai nilai kultur yang dianut. Dan hal ini, menurut an-Na'im, hanya bisa dicapai bila umat Islam siap untuk mendesakralisasi (melakukan tafsir ulang terhadap sumber hukum tekstual) Hukum Pidana Islam dan membawanya sesuai dengan alur sejarah manusia itu sendiri, bukan malah melepaskannya dari dimensi ruang dan waktu sejarah peradaban umat manusia, untuk mewujudkan cita Hukum Islam yang secara filsafati terkandung dalam maqasid al syariah yakni kemaslahatan atau rahmat bagi alam semesta (rahmatan lil 'alamin). 


\section{PENUTUP}

\section{Kesimpulan}

Rekonstruksi pemidanaan dalam

Hukum Pidana Islam dapat dilakukan dengan jalan melakukan desakralisasi (melakukan tafsir ulang terhadap sumber hukum tekstual) Hukum Pidana Islam dan membawanya sesuai dengan alur sejarah manusia itu sendiri, bukan malah melepaskannya dari dimensi ruang dan waktu sejarah peradaban umat manusia, untuk mewujudkan cita Hukum Islam yang secara filsafati terkandung dalam maqasid al syariah yakni kemaslahatan atau rahmat bagi alam semesta (rahmatan lil ‘alamin).

\section{Saran}

Perlu adanya satu kesepahaman antara para Ulama Islam dan ahli Hukum Islam untuk merumuskan ulang pemidanaan dalam Hukum Pidana Islam. Dan perlunya banyak penelitian yang dilakukan terkait dengan pemidanaan dalam Hukum Pidana Islam dari para Sarjana Hukum atau para sarjana yang memiliki ketertarikan terhadap pengembangan Hukum Pidana Islam.

\section{DAFTAR PUSTAKA}

\section{- Buku-Buku :}

A. Rahman Ritonga, dkk., 1997, Ensiklopedi Hukum Islam, Jakarta: Ichtiar Baru Van Hoeve. Abdul Salam, 1987, Fiqh Jinayat (Hukum Pidana Islam), Yogyakarta: Ideal.

Abdullahi Ahmed al Na'im, 1990, Toward in Islamic Reformation, Syracuse, New York: Syracuse University Press.

Abu Ishaq al Syatibi,2004 al Muwafaqat fi Ushul al Syariah, Dar al Kutub al Ilmiah, Beirut. Al Ghazali, 1957, al Mustasyfa, Dal al Fikr, Beirut.

Al Hajjawiy, Syaraf al Din Musa, al Iqna', Penerbit : al Misriyyah, cet. I, jilid IV, tt. ;

Al-Jawziyah, Ibn Al-Qayyim, 1955, I'lam al-Muwaqqi'in, jilid II, Cairo: Dar al-Fikr.

Al-Mawardi, al-Ahkam al-Sulthaniyyah, Beirut: Dar al-Kitab al-'Arabi, 1380 H.;

Awdah, Abd. Al-Qadir, al-Tasyri' al-Jina'l al-Islami, Bairut: Dar al-Fikr, t.t.;

Mohammed S El-Awa, 1982, Punishment in Islamic Law, Indianapolis: American Trust Publications.

Goodhart, Arthur Lehman, 1953, English Law and the Moral Law, London: Stevens.

Gunarto, Prof, Dr. SH., SE., Akt., M.Hum., Materi Kuliah Filsafat Hukum, disampaikan pada perkuliahan Program Doktyor IImu Hukum UNISSULA Semarang, pada tanggal 26 Oktober 2013

Hammam, Ibnu, Syarah Fath al Qadir, Jilid IV, tt.

Ibnu Taimiyah, al Ikhtibarat al Ilmiyah, Penerbit Kurdistan, tt.;

Izzuddin Ibn Abd al-salam, Qawaid al-Ahkam fi Mashalih al-Anam, Dar al-Jail, Beirut, tt.;

Jazuli, 1997, Fiqh Jinayat: Upaya Menanggulangi Kejahatan dalam Islam, Jakarta: Rajawali Press.

Kementerian Urusan Agama Islam Kerajaan Arab Saudi, Al Qur'an dan Terjemahannya, $1419 \mathrm{H}$;

Khallaf, Abdul Wahab,1978, IImu Ushul al Fiqh, Dar al Qalam, Kuwait. 
Mackey Virginia 1983, Punishment in the Scripture and Tradition of Judaism, Christianity and Islam, New York: National Interreligious Task Force on Criminal Justice.

Ma'luf, Louis, al Munjid, Dar al Masyriq, Beirut, 1986;

Marsum,1988, Hukum Pidana Islam, Yogyakarta: Fakultas Hukum UII.

Munajat, Makhrus, Hukum Pidana Islam di Indonesia, Yogyakarta: Bidang Akademik_UIN Sunan Kalijaga, 2008;

Muhammad Abu Zahrah, 2008, Ushul Fiqh, Pustaka Firdaus, Jakarta, 2008;

Muhammad Qutb, 1967, Manhaj al-Tarbiyyah al-Islamiyyah, Beirut: tp.

Sa'id, Rifyal Ka'bah dan Bustami, 1987, Reaktualisasi Ajaran Islam: Pembaharuan Agama Visi Modernis dan Pembaharuan Agama Visi Salaf, Jakarta: Minaret.

M. Hasbi Ash-Shiddiqie, Filsafat Hukum Islam, Jakarta: Bulan Bintang.

R. Soenarto Soerodibroto,1991, KUHP dan KUHAP, PT. Raja Grafindo Persada, Edisi kelima, Jakarta.

Zakaria, Abu Husain Ahmad bin Faris bin, Mu'jam Maqayis al-Lughah, Beirut: Dar al-Fikr li al-Thaba'ah wa al-Nasyr, 1979, Vol.1.

Zimring, Franklin E.,1973, Deterrence: The Legal Threat in Crime Control, Chicago: University of Chicago Press;

Wahbah al Zuhaili, Ushul al-Fiqh al-Islami, Dar al-Fikr, Beirut, 1986, Jilid II; 